\title{
sciendo
}

DOI: $10.2478 / f v-2020-0031$

FOLIA VETERINARIA, 64, 4: 1-8, 2020

\section{MOLECULAR DETECTION AND IDENTIFICATION OF PIROPLASMS IN SEMI-INTENSIVELY MANAGED CATTLE FROM ABEOKUTA, NIGERIA}

\author{
Famuyide, I. M. ${ }^{1}$, Takeet, M. I. ${ }^{2}$, Talabi, A. O. ${ }^{1}$, Otesile, E. B. ${ }^{1}$ \\ ${ }^{1}$ Department of Veterinary Medicine \\ ${ }^{2}$ Department of Veterinary Microbiology and Parasitology, Federal University of Agriculture, Abeokuta \\ Nigeria
}

adeyerimi@gmail.com

\section{ABSTRACT}

Piroplasmosis is a tick-borne haemolytic disease caused by different species of the Babesia and Theileria genera. Data on the prevalence of bovine piroplasms and their genetic diversity are scanty in Nigeria. Hence, this study reported the detection of some piroplasms in the blood of cattle in Abeokuta, Nigeria by the polymerase chain reaction (PCR). Blood samples were collected from 252 cattle and subjected to DNA extraction followed by PCR amplification of the partial region of $18 S$ rRNA of the haemoprotozoans. Selected positive amplicons were unidirectionally sequenced and compared to the reference sequences from the Genbank. A total of $220(87.3 \%)$ cattle were positive for Theileria velifera and/or Babesia bigemina. The T. velifera was detected only in $163(64.7 \%)$ cattle, while $7(2.8 \%)$ cattle had a single infection with $B$. bigemina. Fifty cattle (19.8\%) had mixed infections with both parasites. There were no significant differences in piroplasm infections between the ages of cattle for both parasites. There were no significant differences in infection rates between the sexes for T. velifera, while the males had a significantly higher $(P<0.05)$ rate of infection for $B$. bigemina than the female cattle. The molecular detection of Babesia and Theileria species of cattle are reported for the first time in cattle in Abeokuta, Nigeria. This study, which confirmed the endemic nature of the parasites in cattle in the study area, stresses their importance in livestock health and production in Nigeria.

Key words: Abeokuta; Babesia bigemina; cattle; Nigeria; piroplasm; 18S rRNA; Theileria velifera

\section{INTRODUCTION}

Apart from the fact that bovine piroplasmosis poses a threat to cattle production worldwide with a negative impact on protein supply, it is also an important emerging zoonosis affecting human health [15]. Piroplasmosis is a tickborne disease of domestic and wild animals. The disease in cattle is caused by an intracellular protozoan parasites of the genus Babesia, that infect red blood cells (RBC) only, 
and Theileria species which may be found in white blood cells in addition to RBC [37]. Piroplasms are transmitted by the members of the family Ixodidae [36].

Bovine babesiosis is caused mostly by B. bovis, $B$. bigemina and $B$. divergens $[6,25]$. Other important Babesia spp. includes B. orientalis, B. major, and B. ovata. Babesiosis is prevalent all over the world with over half of the global cattle population at risk [7]. Babesia species are transmitted by the tick of the genus Boophilus (Rhipicephalus) spp. [6, 29]. The disease is characterized by fever and severe intravascular haemolysis, leading to anaemia, icterus, haemoglobinuria, neurologic signs in some subjects and death if not attended to in time [21]. The fever during infections may cause pregnant cattle to abort and bulls to show reduced fertility lasting six to eight weeks [9]. The pathogenicity of the parasite is dependent on strain, species, and breed of the infected animal; however, animals that survive from the infection generally become carriers of the parasite and serve as reservoirs for transmission [10]. Theileriosis in cattle is caused by the intracellular protozoan of the genus Theileria, especially Theileria parva and Theileria annulata that cause the complex syndromes known as East Coast Fever (ECF) and tropical (Mediterranean) theileriosis, respectively [34]. Theileria taurotragi, T. mutans and T. velifera are also responsible for bovine theileriosis in Africa [22]. The Theileria spp. are closely related to the Babesia spp. phylogenetically [5].

In Nigeria, ruminants including cattle contributes more than seventy percent of protein consumed by the populace and singly contributes about $12.7 \%$ of the agricultural Gross Domestic Product (GDP) [19], but the production and establishment of profitable and sustainable cattle ventures is greatly hampered by haemoparasitic diseases among which piroplasmosis is the second most important disease after trypanosomosis $[15,16]$. This has made the introduction, adaptation, and multiplication of exotic breeds of cattle in Nigeria a challenge.

None-the-less, there is insufficient data on the prevalence and genotypes of piroplasms that exist in different geographical regions of the world [8]. There is a dearth of information on bovine piroplasmosis in Ogun, a state that shares borders with Benin Republic through which animals are grazed from Burkina Faso, Niger Republic, Mali, Togo, and Cote d'Ivoire into Nigeria. Hitherto, diagnosis and epidemiological research on bovine piroplasmosis in Nigeria were commonly done using conventional parasi- tological techniques $[2,3,27,30]$, which most of the time could not differentiate different forms of piroplasms.

To date, only one study [22] applied the Polymerase Chain Reaction technique for detection of piroplasms in cattle in the northern part of Nigeria. Also, $\mathrm{H}$ a $\mathrm{p}$ i et al. [13] recently reported the detection of Babesia and Theileria species in the blood of cattle sampled from an abattoir in Ibadan, a city in the southern part of Nigeria. To the best of our knowledge, no study has described the molecular characteristics and the genetic diversity of piroplasms present in the blood of cattle in the study area. Here, the prevalence and molecular characteristics of piroplasms in the blood of apparently healthy cattle in the environs of Abeokuta, a south-western city in Nigeria were assessed.

\section{MATERIALS AND METHODS}

\section{Sample area, animal, and sample collection}

This study was approved by the Ethical Committee, College of Veterinary Medicine, Federal University of Agriculture Abeokuta, Nigeria, before embarking on this project. The ethical clearance number is FUNAAB/COLVET/ CREC/2012/032.

This study was carried out in the environs of Abeokuta, Ogun State, South West Nigeria. It borders Lagos State and Atlantic Ocean to the south, Oyo and Osun States to the North, Ondo State to the east and the Republic of Benin to the west. The State lies approximately within latitude $7^{\circ} 31.98^{\prime} \mathrm{N}$ and longitude $3^{\circ} 49.65^{\prime} \mathrm{E}$ in the humid tropical lowland region [26].

A total of 252 cattle of different sexes and ages were examined and randomly sampled between January and March 2013. All animals were owned by small holder farmers and were apparently healthy at the time of sampling. Based on rostral teeth development [20], the animals were classified as young (less than 2 years old), and adult (two years and above). Animals with a history of treatment with anti-babesial drugs less than two weeks prior to sampling were excluded from the study. Blood samples were collected aseptically from the jugular vein of each cattle into $5 \mathrm{ml}$ tubes containing disodium ethylene diamine tetraacetic acid (EDTA) as an anticoagulant using a sterile needle and syringe. The blood samples were transported on ice packs to the laboratory and were stored at $4{ }^{\circ} \mathrm{C}$ prior to analysis. 


\section{Genomic DNA extraction and detection of piroplasms by nested Polymerase Chain Reaction}

Genomic DNA was extracted from the EDTA-blood using Quick-gDNA ${ }^{\mathrm{m}}$ MiniPrep (Zymo Research Corporation, Irvine, CA 92614, U.S.A.) as previously described [31]. The eluted DNA in $1.5 \mathrm{ml}$ microcentrifuge tubes were stored at $-20^{\circ} \mathrm{C}$ until use. Three sets of previously published primers targeting the 18S rRNA gene were selected for optimization [14]. The PCR was performed in a $20 \mu \mathrm{l}$ final reaction volume containing the equivalent of $20 \mathrm{ng}$ of genomic DNA, $10 \mathrm{mM}$ Tris- $\mathrm{HCl}, \mathrm{pH} 8.3,1.5 \mathrm{mM} \mathrm{MgCl}_{2}$, $50 \mu \mathrm{M} \mathrm{KCl}, 200 \mu \mathrm{M}$ each of dNTPs, $40 \mathrm{ng}$ of each of the primers and 1unit of Thermus aquaticus DNA polymerase (Bioneer, USA). The reactions were placed in MJ MiniTMpersonal cycler (BIORAD, USA). The reaction conditions were as follows: Conventional PCR for piroplasms using primers AF (5'-ACCTGGTTGATCCTGCCAG-3') and BR (5'- CCATTTATTAGCTTTGTTGC-3') involved an initial denaturation at $94^{\circ} \mathrm{C}$ for $30 \mathrm{sec}$ followed by 45 cycles of denaturation at $94^{\circ} \mathrm{C}$ for $15 \mathrm{sec}$, annealing at $60{ }^{\circ} \mathrm{C}$ for $15 \mathrm{sec}$, and an extension step at $68^{\circ} \mathrm{C}$ for $2 \mathrm{~min}$. This was then followed by a final extension step at $68^{\circ} \mathrm{C}$ for 7 min. Nested PCR for Theileria spp. using primers AN (5'-GCTTGTCTTAAAGATTAAGCCATGC-3') and BN: (5'CGACTTCTCCTTCCTTTAAGTGATAAG-3') involved an initial denaturation at $94^{\circ} \mathrm{C}$ for $30 \mathrm{sec}$, followed by 45 cycles of denaturation at $94^{\circ} \mathrm{C}$ for $15 \mathrm{sec}$, annealing at $60^{\circ} \mathrm{C}$ for $15 \mathrm{sec}$, and extension at $68^{\circ} \mathrm{C}$ for $2 \mathrm{~min}$. This was then followed by a final extension at $68^{\circ} \mathrm{C}$ for $7 \mathrm{~min}$. Nested PCR for Babesia spp. using the primers BB (5'-GCGTTTATTAGTTCGTTAACC-3') and BN (5'- CGACTTCTCCTTCCTTTAAGTGATAAG-3') involved an initial denaturation at $94^{\circ} \mathrm{C}$ for $30 \mathrm{sec}$, followed by 45 cycles of denaturation $94^{\circ} \mathrm{C}$ for $15 \mathrm{sec}$, annealing at $56^{\circ} \mathrm{C}$ for $15 \mathrm{sec}$, and extension at $68^{\circ} \mathrm{C}$ for $2 \mathrm{~min}$. This was then followed by a final extension at $68^{\circ} \mathrm{C}$ for $7 \mathrm{~min}$. Ten microliters of the PCR products were electrophoresed through $1.5 \%$ agarose gel in $1 \times$ TAE ( $40 \mathrm{mM}$ TRIS-acetate and $1 \mathrm{mM}$ EDTA) at $90 \mathrm{~V}$ for $45 \mathrm{~min}$. along with $10 \mu \mathrm{l}$ of biological marker, GENEMateQuanti-Marker, $100 \mathrm{bp}$ DNA ladder (BioExpress, UT, USA). Gels were stained with GelRed(R) Nucleic Acid Stain (PHENIX Research Product, Candler, NC, U.S.A) at $5 \mu \mathrm{l} / 100 \mathrm{ml}$ of the agarose gel suspension. Then PCR products were visualized using an ultraviolet transilluminator (SpectrolineR TC $312 \mathrm{E}$ ).

\section{Sequencing and phylogenetic analysis}

To confirm our results, five PCR products showing expected band sizes for Babesia and Theileria spp. respectively, were randomly selected and unidirectionally sequenced using the forward primers ( $\mathrm{AN}$ and $\mathrm{BB}$ for Babesia and Theileria respectively) in a commercial molecular laboratory (Sequetech, Mountain View, California, USA). The obtained sequences were assembled and edited manually using BioEdit ${ }^{\circledast}$ (version 7.0.9.0.) [12]. Search for homologous sequences in Gene bank were performed using BLASTn (www.ncbi.nlm.nih.gov/BLAST/). The sequences were aligned with each other and published 18S rRNA gene sequences of Babesia spp. and Theileria spp. using the Molecular Evolutionary Genetic Analysis (MEGA 5.05) software [32]. Phylogenetic trees were constructed using the Maximum Likelihood (ML) and Unweighted (UPGMA) algorithms of the phylogeny program of MEGA 5.05 [32]. Plasmodium falciparum (AJ250700) was used as the out group. The bootstrap confidence interval of the tree was determined based on 1000 replicates.

\section{Statistical analysis}

The raw data were entered into a Microsoft Excel spread sheet and descriptive statistics used to summarize the data. SPSS 16.0 was used for the data analysis. The prevalence of piroplasm infection was compared using chi-square test. $\mathrm{P}<0.05$ was considered statistically significant.

\section{RESULTS}

\section{Animals}

Of the 252 cattle sampled, males were 95, while females were 157. As regards age, 117 cattle were young while 135 cattle were adults.

\section{Detection of piroplasms by PCR}

The electrophoresed DNA products after amplification with the sets of primary and secondary primers revealed amplicon sizes of 1467 bp and 1588 bp corresponding to expected band sizes of Babesia and Theileria species 18S rRNA respectively [14]. Out of 252 blood samples examined, piroplasm DNA was detected in the blood of 220 (87.3\%) of the cattle examined. Of these, $163(64.7 \%)$ accounted for Theileria spp. only, 7 (2.8\%) for Babesia only and 50 (19.8\%) had co-infection with both Theileria and Babesia. 
Age, and gender variations among cattle infected with piroplasms

Table 1 reveals the effects of age and sex on the prevalence of the parasites. As regards age, the young cattle had a significantly higher Babesia infection than adults while there was no significant difference in Theileria infection between the two age groups. Male cattle were more predisposed to infection than females for Babesia while no difference was observed between the sexes for Theileria.

Table 1. Effect of age and sex on the prevalence of Babesia and Theileria in cattle

\begin{tabular}{lccc}
\hline Parameters & $\begin{array}{c}\text { Number } \\
\text { of cattle }\end{array}$ & $\begin{array}{c}\text { Babesia species } \\
\text { Number positive } \\
{[\%]}\end{array}$ & $\begin{array}{c}\text { Theileria species } \\
\text { Number positive } \\
{[\%]}\end{array}$ \\
\hline Age & & & $102(87.2)^{\mathrm{a}}$ \\
\hline Young & 117 & $33(28.2)^{\mathrm{a}}$ & $111(82.2)^{\mathrm{a}}$ \\
Adult & 135 & $24(0.18)^{\mathrm{b}}$ & \\
\hline Sex & & & $84(88.4)^{\mathrm{a}}$ \\
\hline Male & 95 & $32(33.7)^{\mathrm{a}}$ & $129(82.2)^{\mathrm{a}}$ \\
\hline Female & 157 & $25(15.9)^{\mathrm{b}}$ & $\mathbf{2 1 3 ( 8 4 . 5 )}$ \\
\hline Total & $\mathbf{2 5 2}$ & $\mathbf{5 7 ( 2 2 . 6 )}$ &
\end{tabular}

In each parameter, the values with different superscript in each column show significant differences $(P<0.05)$

\section{Sequences and phylogenetic analysis}

Three and four readable sequences of Babesia and Theileria, respectively were analysed in this study. The homology search revealed the partial sequences of $18 \mathrm{~S}$ rRNA gene of Theileria spp. from this study had $97 \%$ to $98 \%$ homology with T. velifera with accession numbers KU206307 and FJ869897, respectively from Uganda and Mozambique. That of Babesia spp. had homology scores of between 95-98\% with those sequences of B. bigemina available in the GenBank database. The partial sequences lengths of T. velifera ranged from 618 to 985 bp with a mean G/C content of $44.43 \%$.

Phylogenetic analysis carried out involved those partial sequences of $18 \mathrm{~S}$ rRNA gene obtained from GenBank database. These included: Theileria velifera (AF097993, JN572705) Theileria ovis (AY508455), Theileria cervi (AY735122), Theileria spp. (U97054), Theileria capreoli (AY726011), Theileria spp. Giraffe (FJ213582), Theileria mutans (FJ869898, AF078815, KU206320 and JN572698), B. bigemina (HQ264113, JN714975, HQ840959, AY603402,
FJ426361, EF458191, JQ437264, EF458206 and DQ785311) and B. bovis sequences (L19078 and L19077). The tree was rooted on Plasmodium 18S rRNA gene sequences as an out-group.

Alignment and phylogenetic analysis of the sequences of T. velifera and B. bigemina from this study and those from GenBank revealed that the two genera clustered to form two separate clades (Fig. 1). The phylogenetic trees inferred by both algorithms exhibited almost the same topology placing the sequences of T. velifera isolates from this study in the same clade with T. velifera sequences from Africa (AF097993 and KU206307) with the T. mutans separated into different cluster. All the sequences of B. bigemina from this study clustered in the same clade with those from Europe (DQ785311, FJ426361), USA (HQ264113, EF458206) and Asia (JN714975, HQ840959). Also, one each of the autochthonous B. bigemina and T. velifera sequences clustered into separate taxa with very high nodal value within the clades formed by B. bigemina and T. velifera.

The percentage of replicate trees in which the associated taxa clustered together in the bootstrap test (1000 replicates) is shown next to the branches (>50\% cut-off). B. bigemina $(\mathrm{ABKN} 1-3)$ and $T$. velifera $(\mathrm{ABKN} 2-5)$ are those piroplasms detected in this study.

\section{DISCUSSION}

Limited data exist on the epidemiology of piroplasms of cattle in Nigeria, despite being a major disease of cattle. This study provided some useful data on the prevalence and genetic characteristics of some haemoparasites of cattle in Abeokuta, Nigeria. The presence of Babesia and Theileria in the blood of cattle in Abeokuta were detected using conventional and nested PCR protocol and sequences analysis of amplified partial region of $18 \mathrm{~S}$ rRNA gene.

The White Fulani breed of cattle accounted for most of the sampled animals. The high numbers of the breed could be due to their tolerance to the highly endemic trypanosomosis coupled with their high reproductive and feed conversion rate $[28,33]$.

The prevalence of piroplasmosis due to Babesia spp. and or Theileria spp. reported in this study is higher than previously reported in Nigeria [2, 3, 18, 27]. These investigators employed microscopy techniques for their study. Differentiating piroplasms based only on morphology 


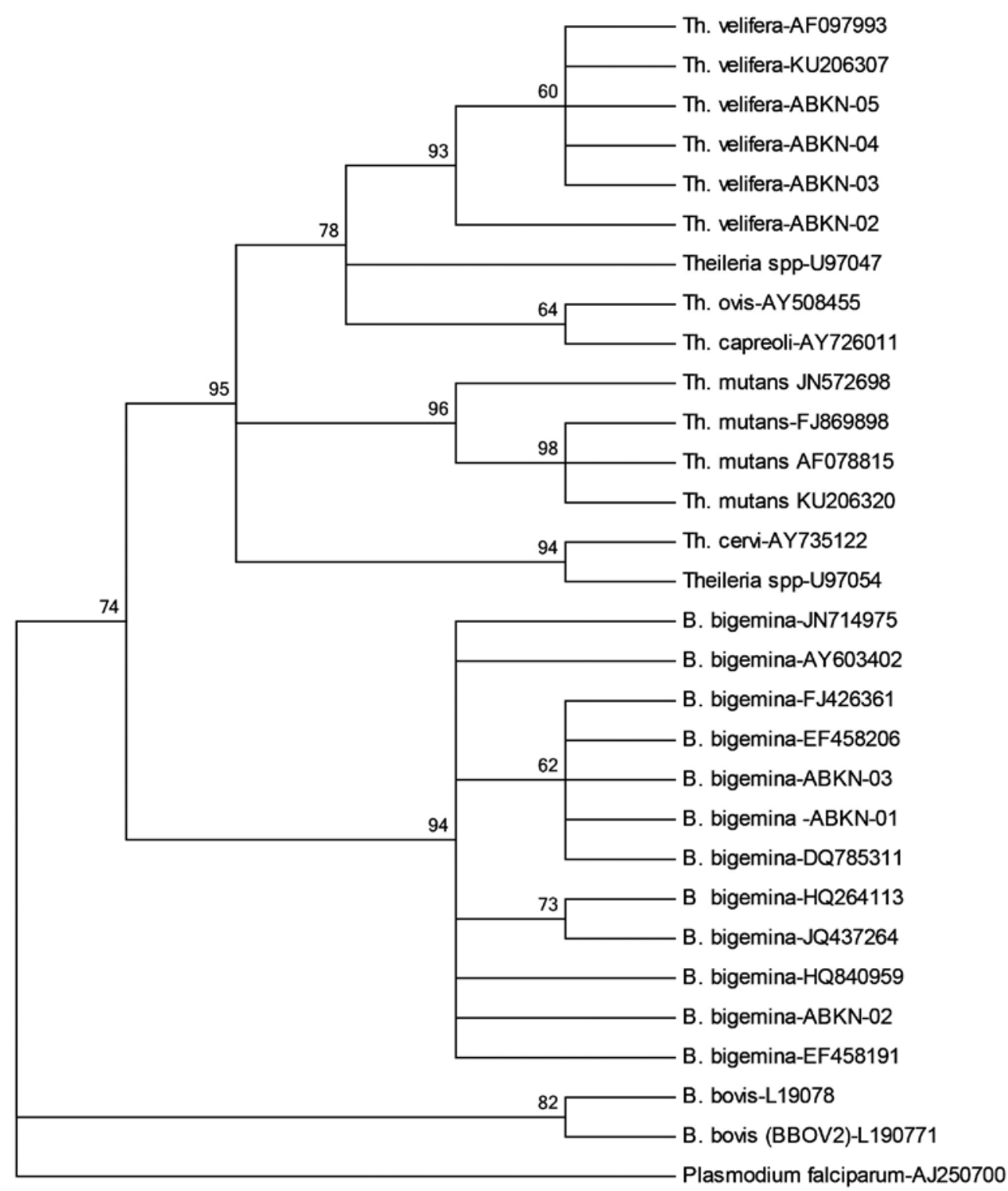

Fig. 1. Evolutionary relationship of piroplasms (B. bigemina and T. velifera) detected in cattle from Abeokuta, Nigeria, using partial sequences of 18S rRNA gene inferred with Maximum Likelihood (ML) and Unweighted Pair Group Method with Arithmetic Mean (UPGMA) in MEGA 5.05. The percentage of replicate trees in which the associated taxa clustered together in the bootstrap test (1000 replicates) is shown next to the branches (> $50 \%$ cut-off). B. bigemina (ABKN 1-3) and T. velifera (ABKN 2-5) are those piroplasms detected in this study

using microscopy is often challenging because these two parasites share a similar morphology, making identification particularly difficult if mixed infections occur. Also, the identification of Babesia parasites is difficult at the onset of the disease and in carrier animals due to the low number of the parasites present [23] which may lead to a false negative diagnosis [4]. In comparison to our findings, L o r u s s o et al. [22] recorded a lower prevalence of B. bigemina (7.9\%) and T. velifera (52.4\%) in cattle from the northern part of Nigeria. In another study, $\mathrm{H}$ a $\mathrm{p}$ i et al. [13] amplified the 18S rRNA region of piroplasms detected in the blood of slaughtered cows in Ibadan, Nigeria and recorded a prevalence of $46 \%$ for Babesia/Theileria spp. The high prevalence of T. velifera in this study, and that of L o r u s s o et al. [22], supports the assertion of the latter workers that the parasite is endemically established or stable in Nigeria.

In the present study, young cattle (less than two years old) had a significantly higher rate of infection with Babesia spp. compared to the adult cattle. As for the infection with Theileria, no significant association with age was noticed. In contrast to our findings, most studies suggest that 
younger cattle (less than 1 year old) have lower infection rates than older ones, probably due to the protective effects of maternal immunity $[1,13,22]$. The wider age group in this study might have obfuscated the effect of age on the prevalence of Babesia species.

Male cattle had a higher rate of Babesia species infection in this study which agrees with the report of $\mathrm{H}$ a $\mathrm{p} \mathrm{p}$ i et al. [13] who also noted a higher prevalence of piroplasms (Babesia/Theileria) in male cattle. Unlike Babesia, there was no significant difference in infection with Theileria spp. between males and females in our study.

In our study, the overall prevalence of piroplasms was $87.3 \%$. The high prevalence may reflect a high endemic level of blood parasites of cattle in the Abeokuta environs. This could indicate that cattle in the studied area were exposed to a high and continuous challenge with piroplasms or that these species were harboured for long periods at detectable levels post-infection. Endemic (or enzootic) stability refers to a state of high level of challenge with haemoparasite-infected ticks and a concurrent low incidence of clinical disease in the host [17]. It may also mean that the vectors of the parasite breed well in this environment. During our study, ticks were present on most of the cattle sampled.

The polymorphism shown by the multiple alignment analysis of the autochthonous sequences may indicate continuous genetic exchange between these parasites in the tick gut or a gene reassortment within the mammalian host in which asexual reproduction takes place [11, 24]. Although $18 \mathrm{~S}$ rRNA gene has been studied extensively to understand the genetic diversity of piroplasms around the world, this is, to the best of our knowledge, the first time it is being used to shed light on the genetic diversity of bovine piroplasms in Abeokuta, Nigeria. None-theless, for a better understanding of this diversity among the piroplasms circulating in the cattle population in Nigeria, there is a need to employ the analysis of other gene regions such as cytochrome $\mathrm{C}$ oxidase subunit III (COX3) and Mitochondria cytochrome $\mathrm{B}(\mathrm{COB})$ genes which have been claimed to give an improved phylogeny of piroplasms in China [35].

Although the pathogenicity of T. velifera has not been studied extensively in Nigeria, the suggestion of more than one strain by phylogenetic analysis calls for further studies to elucidate the strain distribution and associated pathogenicity in cattle in Nigeria.

\section{CONCLUSIONS}

This study confirmed the presence of piroplasms, notably B. bigemina and T. velifera in the blood of cattle in the study area with $T$. velifera being more prevalent. The results of our study have provided additional molecular data on the epidemiology of piroplasms of cattle in Nigeria. The information may be useful for the diagnosis and effective formulation of control strategies. Further studies covering all regions of Nigeria should be conducted to generate and co mpare the prevalence data for the distribution of tick transmitted parasites in livestock, especially cattle in the country.

\section{ACKNOWLEDGEMENT}

Mr. Olugbogi, E. I. of the Department of Veterinary Microbiology and Parasitology is acknowledged for providing technical support during this study.

\section{REFERENCES}

1. Ademola, I., Onyiche, T., 2013: Haemoparasites and haematological parameters of slaughtered ruminants and pigs at Bodija abattoir, Ibadan, Nigeria. Afr. J. Biomed. Res., 16, $101-105$.

2. Akande, F., Takeet, M., Makanju, O., 2010: Haemoparasites of cattle in Abeokuta, South West Nigeria. Sci. World J., 5, 4, $19-21$.

3. Akinboade, O., Dipeolu, O., 1984: Comparison of blood smear and indirect fluorescent antibody techniques in detection of haemoparasite infections in trade cattle in Nigeria. Vet. Parasitol., 14, 95-104. DOI: 10.1016/0304-4017(84)90116-X.

4. Almería, S., Castella, J., Ferrer, D., Ortuno, A., Estrada-Peña, A., Gutierrez, J., 2001: Bovine piroplasms in Minorca (Balearic Islands, Spain): a comparison of PCR-based and light microscopy detection. Vet. Parasitol., 99, 249-259. DOI: 10.1016/S0304-4017(01)00464-2.

5. Bishop, R., Musoke, A., Morzaria, S., Gardner, M., Nene, V., 2000: Theileria: intracellular protozoan parasites of wild and domestic ruminants transmitted by ixodid ticks. Parasitology, 129, 271-283. DOI: 10.1017/S0031182003004748.

6. Bock, R., Jackson, L., De Vos, A., Jorgensen, W., 2004: Babesiosis of cattle. Parasitology, 129 (Suppl.), 247-269. DOI: $10.1017 /$ S0031182004005190. 
7. Brayton, K. A., Lau, A. O., Herndon, D. R., Hannick, L., Kappmeyer, L. S., Berens, S. J., et al., 2007: Genome sequence of Babesia bovis and comparative analysis of apicomplexan hemoprotozoa. PLoS pathogens, 3, e148. DOI: 10.1371/ journal.ppat.0030148.

8. Cao, S., Aboge, G. O., Terkawi, M. A., Yu, L., Kamyingkird, K., Luo, Y., et al., 2012: Molecular detection and identification of Babesia bovis and Babesia bigemina in cattle in northern Thailand. Parasitol. Res., 111, 1259-1266. DOI: 10.1007/ s00436-012-2960-4.

9. Ferreri, L., Benitez, D., Dominguez, M., Rodriguez, A., Asenzo, G., Mesplet, et al., 2008: Water buffalos as carriers of Babesia bovis in Argentina. Ann. N. Y. Acad. Sci., 1149, 149-151. DOI: 10.1196/annals.1428.036.

10. Figueroa, J., Chieves, L., Johnson, G., Buening, G., 1993: Multiplex polymerase chain reaction based assay for the detection of Babesia bigemina, Babesia bovis and Anaplasma marginale DNA in bovine blood. Vet. Parasitol., 50, 69-81. DOI: 10.1016/0304-4017(93)90008-B.

11. Golgh, J. M., Jorgensen, W. K., Kemp, D. H., 1998: Development of tick gut forms of Babesia bigemina in vitro. J. Eukaryot. Microbiol., 45, 298-306. DOI: 10.1111/j.1550-7408. 1998.tb04540.x.

12. Hall, T. A., 1999: BioEdit: a user-friendly biological seq uence alignment editor and analysis program for Windows 95/98/NT. Nucleic Acids Symposium Series, 41, 95-98.

13. Happi, A. N., Osifade, O., Oluniyi, P. E., Ogunro, B. N., 2020: Comparison of light microscopy and polymerase chain reaction for the detection of haemoparasites in cattle in $\mathrm{Ni}$ geria. Acta Parasitol., 65, 44-56. DOI: 10.2478/s11686-01900123-y.

14. Holman, P. J., Carroll, J. E., Pugh, R., Davis, D. S., 2011: Molecular detection of Babesia bovis and Babesia bigemi$n a$ in white-tailed deer (Odocoileus virginianus) from Tom Green County in central Texas. Vet. Parasitol., 177, 298-304. DOI: 10.1016/j.vetpar.2010.11.052.

15. Homer, M. J., Aguilar-Delfin, I., Telford, S. R., Krause, P. J., Persing, D. H., 2000: Babesiosis. Clin. Microbiol. Rev., 13, 451-469. DOI: 10.1128/CMR.13.3.451.

16. Hunfeld, K. P., Hildebrandt, A., Gray, J., 2008: Babesiosis: recent insights into an ancient disease. Int. J. Parasitol., 38, 1219-1237. DOI: 10.1016/j.ijpara.2008.03.001.

17. Jonsson, N. N., Bock, R. E., Jorgensen, W. K., Morton, J. M., Stear, M. J., 2012: Is endemic stability of tick-borne disease in cattle a useful concept? Trends Parasitol., 28, 85-89. DOI: $10.1016 /$ j.pt.2011.12.002
18. Kamani, J., Sannusi, A., Egwu, O., Dogo, G., Tanko, T., Kemza, S., Tafarki, A., Gbise, D., 2010: Prevalence and significance of haemoparasitic infections of cattle in North-Central, Nigeria. Vet. World, 3, 10, 445-448. DOI: 10.5455/vetworld. 2010.445-448.

19. Kubkomawa, H., 2017: Indigenous breeds of cattle, their productivity, economic and cultural values in Sub-Saharan Africa: A review. Int. J. Res. Stud. Agric. Sci., 3, 27-43. DOI: 10.20431/2454-6224.0301004.

20. Lasisi, O., Ojo, N., Otesile, E., 2002: Estimation of age of cattle in Nigeria using rostral dentition. Trop. Veter., 20, 204-208. DOI: $10.4314 /$ tv.v20i4.4485.

21. Lau, A. O., Tibbals, D. L., McElwain, T. F., 2007: Babesia bovis: the development of an expression oligonucleotide microarray. Exp. Parasitol., 117, 93-98. DOI: 10.1016/j.exppara. 2007.03.004.

22. Lorusso, V., Wijnveld, M., Majekodunmi, A. O., Dongkum, C., Fajinmi, A., Dogo, A. G., et al., 2016: Tick-borne pathogens of zoonotic and veterinary importance in Nigerian cattle. Parasit. Vectors, 9, 217. DOI: 10.1186/s13071-016-1504-7.

23. M'ghirbi, Y., Ros-García, A., Iribar, P., Rhaim, A., Hurtado, A., Bouattour, A., 2013: A molecular study of tick-borne haemoprotozoan parasites (Theileria and Babesia) in small ruminants in Northern Tunisia. Vet. Parasitol., 198, 72-77. DOI: 10.1016/j.vetpar.2013.08.005.

24. Mackenstedt, U., Gauer, M., Fuchs, P., Zapf, F., Schein, E., Mehlhorn, H., 1995: DNA measurements reveal differences in the life cycles of Babesia bigemina and B. canis, two typical members of the genus Babesia. Parasitol. Res., 81, 595-604. DOI: $10.1007 / \mathrm{BF} 00932027$.

25. Mtshali, M. S., Mtshali, P. S., 2013: Molecular diagnosis and phylogenetic analysis of Babesia bigemina and Babesia bovis hemoparasites from cattle in South Africa. BMC Vet. Res., 9, 154. DOI: $10.1186 / 1746-6148-9-154$.

26. Obayelu, O., Akintunde, O., Obayelu, A., 2015: Determinants of on-farm cassava biodiversity in Ogun State, Nigeria. Int. J. Biodivers. Sci. Ecosyst. Serv. Manag., 11, 298-308. DOI: 10.1080/21513732.2015.1071282.

27. Onoja, I., Malachy, P., Mshelia, W., Okaiyeto, S., Danbirni, S., Kwanashie, G., 2013: Prevalence of babesiosis in cattle and goats at Zaria abattoir, Nigeria. J. Vet. Adv., 3, 211-214. DOI: 10.5455/jva.20130801034405.

28. Otchere, E., 1982: The productivity of White Fulani (Bunaji) cattle in pastoralist herds of the Kaduna Plains, Nigeria. International Livestock Centre for Africa (ILCA) Sub-humid Programme Kaduna. Internal Comm., 46, 27. 
29. Ríos-Tobón, S., Gutiérrez-Builes, L. A., Ríos-Osorio, L. A., 2014: Assessing bovine babesiosis in Rhipicephalus (Boophilus) microplus ticks and 3 to 9-month-old cattle in the middle Magdalena region, Colombia. Pesqui Vet. Bras., 34, 313-319. DOI: 10.1590/S0100-736X2014000400002.

30. Sam-Wobo, S., Uyigue, J., Surakat, O., Adekunle, N., Mogaji, H., 2016: Babesiosis and other heamoparasitic disease in a cattle slaughtering abattoir in Abeokuta, Nigeria. Int. J. Trop. Dis. Health, 18, 1-5. DOI: 10.9734/IJTDH/2016/27280.

31. Takeet, M. I., Fagbemi, B. O., De Donato, M., Yakubu, A., Rodulfo, H. E., Peters, S. O., et al., 2013: Molecular survey of pathogenic trypanosomes in naturally infected Nigerian cattle. Res. Vet. Sci., 94, 555-561. DOI: 10.1016/j.rvsc. 2012. 10.018 .

32. Tamura, K., Peterson, D., Peterson, N., Stecher, G., Nei, M., Kumar, S., 2010: MEGA5: molecular evolutionary genetics analysis using maximum likelihood, evolutionary distance, and maximum parsimony methods. Mol. Biol. Evol., 28, 2731-2739. DOI: 10.1093/molbev/msr121.
33. Tawah, C., Rege, J., 1996: White Fulani cattle of west and central Africa. Anim. Genet. Resour. Inf., 17, 137-158.

34. Thekisoe, O., Omolo, J., Swai, E., Hayashida, K., Zhang, J., Sugimoto, C., Inoue, N., 2000: Preliminary application and evaluation of loop-mediated isothermal amplification (LAMP) for detection of bovine theileriosis and trypanosomosis in Tanzania: research communication. Onderstepoort J. Vet. Res., 74, 339-342. DOI: 10.4102/ojvr.v74i4.119.

35. Tian, Z., Luo, J., Zheng, J., Xie, J., Shen, H., Yin, H., et al., 2013: Phylogenetic analysis of Babesia species in China based on cytochrome b (COB) gene. Infect. Genet. Evol., 13, 36-40. DOI: 10.1016/j.meegid.2012.09.001.

36. Uilenberg, G., 2006: Babesia-A historical overview. Vet. Parasitol., 138, 3-10. DOI: 10.1016/j.vetpar.2006.01.035.

37. Zhao, S., Liu, J., Zhao, H., Li, Y., Xie, J., Liu, A., et al., 2017: Evaluating an indirect rMPSP enzyme-linked immunosorbent assay for the detection of bovine Theileria infection in China. Parasitol. Res., 116, 667-676. DOI: 10.1007/ s00436-016-5332-7.

Received July 6, 2020

Accepted September 10, 2020 